\title{
2-Butyl-6-phenyl-4,5-dihydropyridazin-3(2H)-one: Synthesis, In Silico Studies and In Vitro Cyclooxygenase-2 Inhibitory Activity
}

\author{
Mohd Imran \\ Department of Pharmaceutical Chemistry, Faculty of Pharmacy, Northern Border University, \\ Rafha 91911, Saudi Arabia; imran.pchem@gmail.com; Tel.: +966-599577945
}

Received: 13 August 2020; Accepted: 26 August 2020; Published: 28 August 2020

\begin{abstract}
Pyridazinone derivatives are a great template for developing cyclooxygenase-2 (COX-2) inhibitors. The 2-butyl-6-phenyl-4,5-dihydropyridazin-3(2H)-one was prepared by reacting 6-phenyl4,5-dihydropyridazin-3(2H)-one with $n$-butyl bromide in the presence of potassium carbonate. The structure of the compound was confirmed based on its FTIR, ${ }^{1} \mathrm{H}-\mathrm{NMR},{ }^{13} \mathrm{C}-\mathrm{NMR}$, and Mass data. The molecular docking studies assessed the COX-2 binding capability of the synthesized compound. The in silico physicochemical and pharmacokinetic parameters of this compound concerning selected drugs were also calculated. The COX-2/COX-1 analysis revealed the synthesized compound as a novel potent COX-2 inhibitor, in comparison to indomethacin, with a promising physicochemical and pharmacokinetic profile.
\end{abstract}

Keywords: pyridazinone; docking; physicochemical; pharmacokinetic; cyclooxygenase-2 inhibitor

\section{Introduction}

The pyridazinone ring is part of many clinically used drugs of different therapeutic categories, including emorfazone (Figure 1), which is used as an analgesic/anti-inflammatory drug [1]. This ring is also considered as a pharmacophore to develop bioactive molecules [2]. The increased level of cyclooxygenase-2 (COX-2) is liable for the generation of the inflammatory procedures in a cell [3] and is considered as an important therapeutic target to develop anti-inflammatory drugs. Recent studies have revealed that pyridazinone derivatives are promising templates for evolving COX-2 inhibitors [4].<smiles>CCOc1c(N2CCOCC2)cnn(C)c1=O</smiles>

Figure 1. Emorfazone.

The titled compound has been disclosed generically as compound $\mathbf{1 b}$ in the literature [5]. As per the exact structure search of the Sci-Finder, its CAS registry number is 1532529-93-3. The chemical structure lookup service (CSLS) (https://cactus.nci.nih.gov/) provided zero hits for the titled compound. In [5] the author is explicitly silent about the synthesis, spectral analysis, in silico studies, and the COX-2 inhibitory profile of the titled compound. Accordingly, the author reports these aspects of the titled compound (after this compound 2) in this communication. 


\section{Results and Discussion}

\subsection{Chemistry}

The preparation of compound 2 was carried out as per reaction Scheme 1, wherein compound 1 was synthesized according to the method described in U.S. Patent Number 4,404,203 [6]. The reaction of compound 1 with $n$-butyl bromide in acetone in the presence of $\mathrm{K}_{2} \mathrm{CO}_{3}$ resulted in the production of compound 2. The FTIR of compound 2 demonstrated a characteristic peak at $1670.56 \mathrm{~cm}^{-1}$ for its $\mathrm{C}=\mathrm{O}$ group. The ${ }^{1} \mathrm{H}-\mathrm{NMR}$ showed a signal for the single methyl group as a triplet $(\delta 0.89-0.91)$. The compound has five methylene groups. The signals for these groups appeared as doublets or triplets at $\delta 1.29-1.31, \delta 1.59-1.61, \delta 2.49-2.52, \delta 2.96-2.98$, and $\delta 3.73-3.75$. The five aromatic protons of compound 2 appeared at $\delta 7.44-7.79$. The ${ }^{13} \mathrm{C}-\mathrm{NMR}$ displayed characteristic peaks for the carbonyl carbon $(\delta 165.40), C=N(\delta 150.83)$, five methylene carbons ( $\delta 47.61$ to 19.76$)$, and the methyl group ( $\delta$ 14.17). The aromatic carbons appeared in their normal range. The mass spectrum of compound 2 also provided the expected molecular ion peak for the assigned structure.

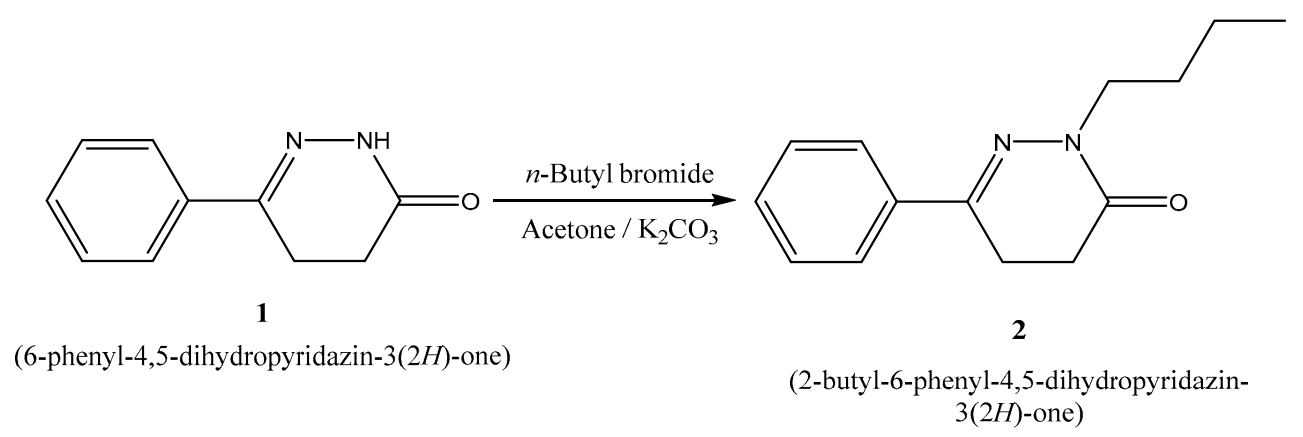

Scheme 1. Preparation of 2-butyl-6-phenyl-4,5-dihydropyridazin-3(2H)-one (Compound 2).

The common chemical identifiers of compound 2 have been provided in Supplementary Table S1.

\subsection{Molecular Docking}

A comparative molecular docking study between compound 2 and selected NSAIDs was performed. Aspirin, diclofenac, indomethacin, naproxen, oxaprozin, and piroxicam are non-specific COX-2 inhibitors, whereas celecoxib is a specific COX-2 inhibitor. The results of the docking study are disclosed in Table 1. Compound 2 had better binding energy (docking score) than aspirin, diclofenac, indomethacin, naproxen, and piroxicam (Figure 2). The calculated values of the inhibition constant (Ki) for compound 2 was less than aspirin, diclofenac, indomethacin, and naproxen. Accordingly, it can be assumed that compound $\mathbf{2}$ has more potent COX-2 inhibition than aspirin, diclofenac, indomethacin,

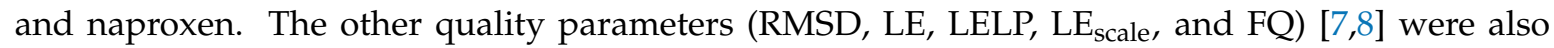
comparable to the selected NSAIDs. The COX-2 is a therapeutic target, whereas COX-1 inhibition causes gastric ulceration effects [9]. Accordingly, the molecular docking study against COX-1 was also carried out. The results of COX-1 docking indicate that compound 2 had a lesser binding affinity for COX-1 than celecoxib, indomethacin, and oxazoprozin. It can be analyzed from Table 1 data that compound 2 had a better potency for COX-2 and lesser potency for COX-1 in comparison to indomethacin. Accordingly, it can be assumed that compound $\mathbf{2}$ can display better anti-inflammatory activity results than indomethacin. Figures 3-5 represent the 2D interactions of celecoxib, indomethacin, and compound 2 with the COX-2 protein, respectively. Figure 3 depicts the interaction of the celecoxib with the COX-2 protein, wherein the sulfonamide moiety interacts with the Arg 513 residue of the protein. This is in concurrence with the literature [10]. This observation supports our docking results. The compound 2 and indomethacin do not show interaction with Arg 513 residue (Figures 4 and 5), which may be a reason for their less selectivity for COX-2 in contrast to celecoxib. 
Table 1. Bioactivity parameters of compound 2 and selected NSAIDs.

\begin{tabular}{cccccccccc}
\hline \multirow{2}{*}{ Compound } & \multicolumn{4}{c}{ Chain B of 5KIR (COX-2) } & \multicolumn{3}{c}{ Chain B of 3KK6 (COX-1) } \\
\cline { 2 - 10 } & DS & RMSD & $\mathbf{K}_{\mathbf{i}}$ & LE & LELP & LEScale & FQ & DS & RMSD \\
\hline $\mathbf{2}$ & -6.83 & 1.26 & 0.0067 & 0.40 & 6.62 & 0.47 & 0.85 & -7.11 & 0.99 \\
Aspirin & -5.33 & 1.49 & 0.020 & 0.41 & 3.12 & 0.53 & 0.77 & -5.60 & 1.28 \\
Celecoxib & -9.14 & 0.97 & 0.0012 & 0.35 & 9.71 & 0.36 & 0.97 & -9.69 & 1.23 \\
Diclofenac & -6.38 & 1.14 & 0.0093 & 0.34 & 10.76 & 0.44 & 0.77 & -6.07 & 1.29 \\
Indomethacin & -6.81 & 1.03 & 0.0068 & 0.27 & 13.44 & 0.37 & 0.73 & -8.59 & 1.04 \\
Naproxen & -6.57 & 1.50 & 0.0082 & 0.39 & 6.92 & 0.47 & 0.83 & -6.19 & 0.65 \\
Oxaprozin & -7.68 & 1.14 & 0.0036 & 0.35 & 9.71 & 0.40 & 0.87 & -7.91 & 0.61 \\
Piroxicam & -5.63 & 0.99 & 0.016 & 0.24 & 5.75 & 0.39 & 0.61 & -6.19 & 0.85 \\
\hline
\end{tabular}

DS = docking scores; RMSD = root mean square deviation; $K_{i}=$ Inhibition constant; LE = Ligand efficiency; LELP = Ligand Efficiency Lipophilic Price; $L_{\text {Scale }}=$ Ligand Efficiency Scale; FQ = Fit Quality.

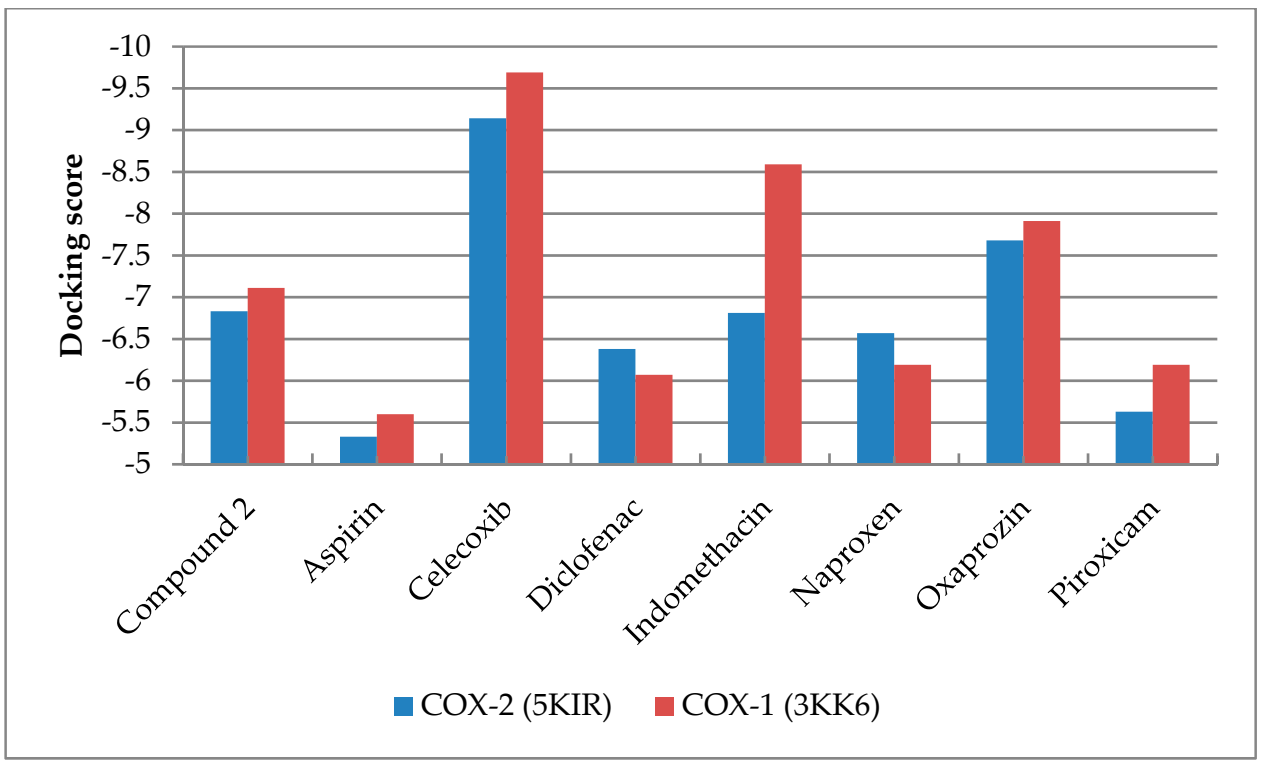

Figure 2. A comparative diagram of docking scores of compound 2 and selected NSAIDs against COX-1/COX-2 proteins. 


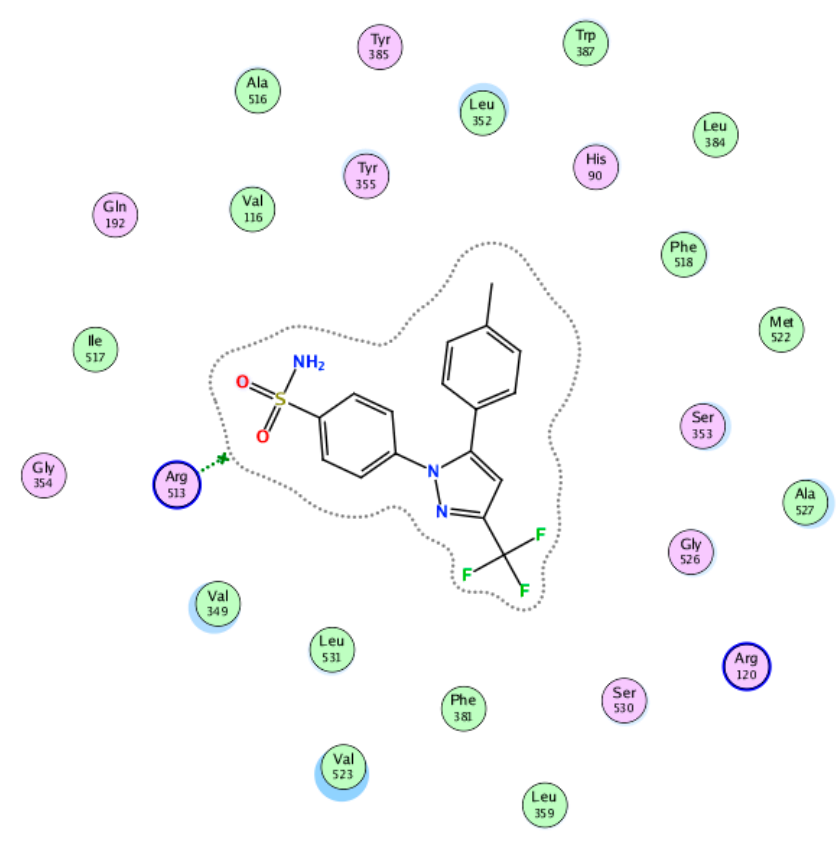

Figure 3. Interaction of celecoxib with COX-2 protein.

$\left(\begin{array}{lll}1204 \\ 352\end{array}\right.$
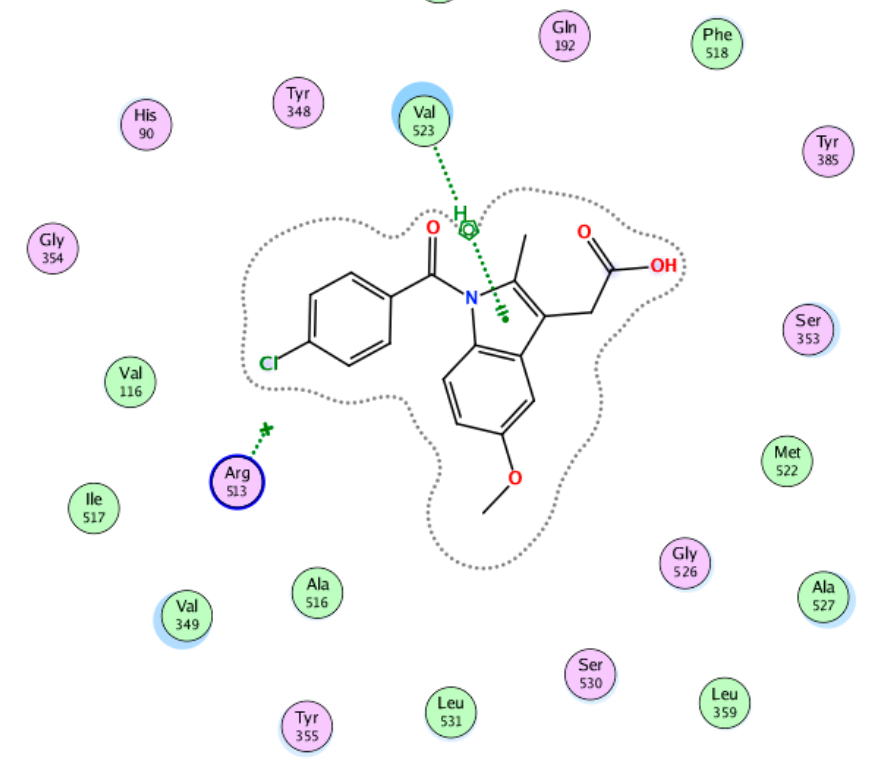

Figure 4. Interaction of indomethacin with COX-2 protein. 


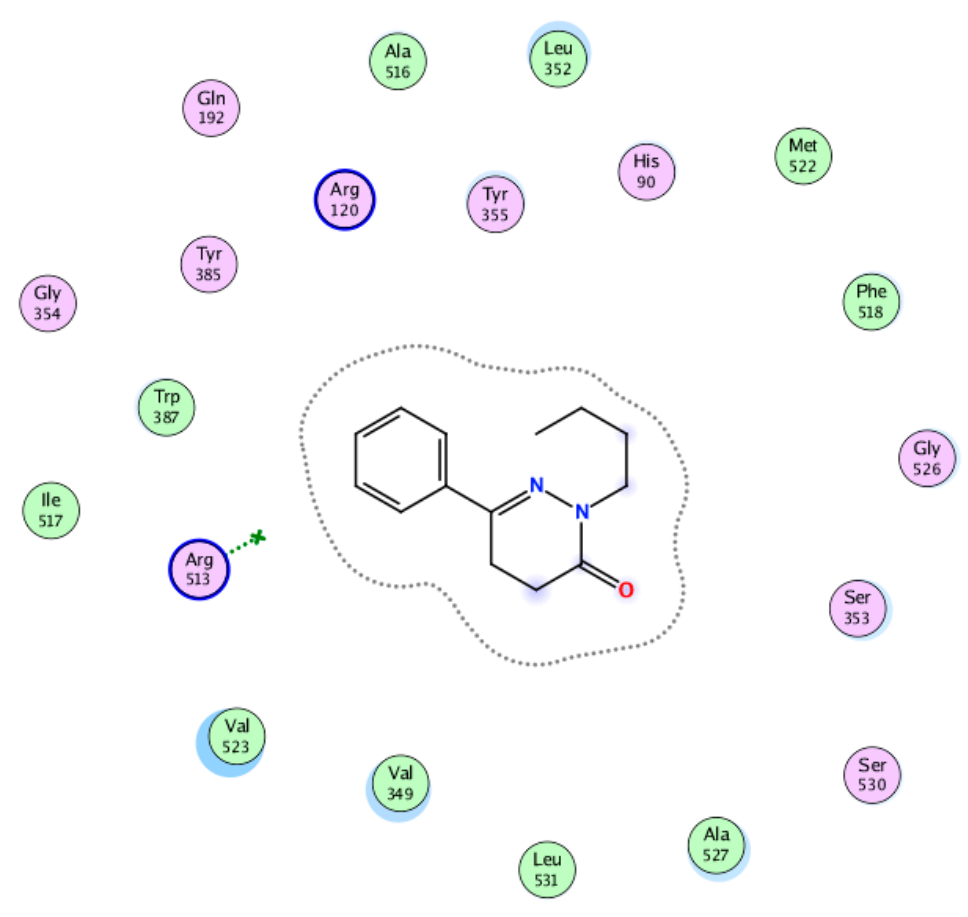

Figure 5. Interaction of compound 2 with COX-2 protein.

\subsection{Physicochemical Properties and Drug-Likeness Analysis}

A comparative physicochemical properties analysis of compound 2 and selected NSAIDs was performed to compare their drug-likeness and the pharmacokinetic parameters. The data are listed in Table 2. The physicochemical properties data of compound 2 were found to be comparable to the selected NSAIDs. The data revealed that compound $\mathbf{2}$ had drug-likeness, bioavailability scores, and GI absorption similar to the selected NSAIDs. To verify the GI absorption data, the absorption was calculated by another method [11,12]. It was surprisingly observed that compound 2 displayed the highest calculated absorption of the selected NSAIDs. Accordingly, we generated the bioavailability radar for compound $\mathbf{2}$ and the selected NSAIDs utilizing the Swiss web server (http://www.swissadme. $\mathrm{ch} /$ ) [13]. Based on the molecular docking data, the bioavailability radar of compound 2, celecoxib, and indomethacin are provided in Supplementary Figure S1. The bioavailability radar of other NSAIDs is provided as supplementary material. The bioavailability radar is based on different parameters like lipophilicity, molecular size, polarity, insolubility, insaturation, and flexibility. The pink area in the figure denotes the appropriate physicochemical space for oral bioavailability. It is quite stimulating to observe that compound $\mathbf{2}$ has a better physicochemical space for oral bioavailability than celecoxib and indomethacin. This also supports our calculated absorption values [11,12]. The BOILED-Egg method [14] is a predictive method to assess the penetration of the small molecules into the brain and absorption from the gastrointestinal tract (http://www.swissadme.ch/). Supplementary Figure S2 represents the BOILED-Egg model of compound $\mathbf{2}$ and selected NSAIDs. This figure indicates a similar absorption pattern of compound 2, indomethacin, naproxen, diclofenac, oxaprozin, and aspirin. It is also observed that compound 2 inhibits fewer enzymes than diclofenac, indomethacin, and oxaprozin. This indicates that compound $\mathbf{2}$ should have less drug-drug interactions than diclofenac, indomethacin, and oxaprozin. The skin permeation data of compound $\mathbf{2}$ were also comparable to the selected NSAIDs. 
Table 2. Comparative physicochemical and ADME parameters of 2 and selected NSAIDs.

\begin{tabular}{|c|c|c|c|c|c|c|c|c|}
\hline Parameter & Compound 2 & Aspirin & Celecoxib & Diclofenac & Indomethacin & Naproxen & Oxaprozin & Piroxicam \\
\hline NHA & 17 & 13 & 26 & 19 & 25 & 17 & 22 & 23 \\
\hline MR & 76.96 & 44.90 & 89.96 & 77.55 & 96.12 & 66.95 & 83.73 & 87.52 \\
\hline $\begin{array}{l}\log \mathbf{P}(\mathbf{o} / \mathbf{w}) \\
\text { (Consensus) }\end{array}$ & 2.65 & $1.19^{\# \#}$ & 3.40 & $4.51^{\# \#}$ & $4.27^{\# \#}$ & $3.18^{\# \#}$ & $4.19^{\# \#}$ & $3.06^{\# \#}$ \\
\hline WS & Moderate & Soluble & Moderate & Moderate & Moderate & Moderate & Moderate & Moderate \\
\hline $\begin{array}{c}\text { GI } \\
\text { absorption }\end{array}$ & $\begin{array}{c}\text { High } \\
(97.72 \%)\end{array}$ & $\begin{array}{c}\text { High } \\
(87.05 \%)\end{array}$ & $\begin{array}{c}\text { High } \\
(79.02 \%)\end{array}$ & $\begin{array}{l}\text { High } \\
(91.98)\end{array}$ & $\begin{array}{c}\text { High } \\
(85.35)\end{array}$ & $\begin{array}{c}\text { High } \\
(92.94 \%)\end{array}$ & $\begin{array}{c}\text { High } \\
(87.15 \%)^{\#}\end{array}$ & $\begin{array}{c}\text { High } \\
(71.75 \%)\end{array}$ \\
\hline $\begin{array}{c}\text { BBB } \\
\text { permeant }\end{array}$ & Yes & Yes & No & Yes & Yes & Yes & Yes & No \\
\hline $\begin{array}{l}\text { CYP2C19 } \\
\text { inhibitor }\end{array}$ & Yes & No & No & Yes & Yes & No & Yes & No \\
\hline $\begin{array}{l}\text { CYP2C9 } \\
\text { inhibitor }\end{array}$ & No & No & Yes & Yes & Yes & No & Yes & Yes \\
\hline $\begin{array}{l}\text { CYP2D6 } \\
\text { inhibitor }\end{array}$ & No & No & No & Yes & No & No & Yes & No \\
\hline $\begin{array}{l}\text { CYP3A4 } \\
\text { inhibitor }\end{array}$ & No & No & No & No & No & No & No & No \\
\hline $\mathrm{SP}(\mathrm{cm} / \mathrm{s})$ & -6.03 & -6.55 & -6.21 & -4.98 & -5.45 & -5.60 & -5.11 & -6.15 \\
\hline
\end{tabular}

NHA = Number of heavy atoms; MR = Molar Refractivity; TPSA = Topological polar surface area; $\log$ P = Lipophilicity; DL = Drug likeness; BS = Bioavailability score; WS = Water solubility; GI = Gastrointestinal; $\mathrm{BBB}=$ Blood-brain barrier; $\mathrm{SP}=$ Skin permeation; \# Calculated absorption $(\% \mathrm{ABS}=109-(0.345 \times \mathrm{tPSA})$; \#\# experimental values (drug bank/pubchem).

\subsection{In Vitro COX-1 and COX-2 Inhibitory Activity}

Compound 2, indomethacin, and celecoxib were subjected for the in vitro studies against COX-1/COX-2 enzymes [9]. This selection of compound 2 and indomethacin was based on the molecular docking studies of compounds against COX-1 and COX-2, and their comparable physicochemical/pharmacokinetic properties data. The celecoxib was used as a standard COX-2 inhibitor [15]. The data of the in vitro study are mentioned in Table 3.

Table 3. In vitro COX-1/COX-2 inhibition assay $(N=3$, Mean $\pm S D)$.

\begin{tabular}{ccccccc}
\hline Compound & $\begin{array}{c}\text { COX-1 } \\
\left(\mathbf{I C}_{\mathbf{5 0}} \text { in } \mathbf{n M}\right)\end{array}$ & $\begin{array}{c}\text { \% COX-1 } \\
\text { inhibition }\end{array}$ & $\begin{array}{c}\text { COX-2 } \\
\left(\mathbf{I C}_{\mathbf{5 0}} \text { in } \mathbf{n M}\right)\end{array}$ & $\begin{array}{c}\text { \% COX-2 } \\
\text { inhibition }\end{array}$ & SI & \%SI \\
\hline $\mathbf{2}$ & $368 \pm 0.22 *$ & $61.95 \%$ & $25.13 \pm 0.31 *$ & $71.78 \%$ & 14.64 & $79.34 \%$ \\
Celecoxib & $333 \pm 0.12 *$ & $68.46 \%$ & $18.04 \pm 0.22 *$ & $100.0 \%$ & 18.45 & $100.0 \%$ \\
Indomethacin & $228 \pm 0.16^{*}$ & $100.0 \%$ & $58.41 \pm 0.18 *$ & $30.88 \%$ & 3.90 & $21.13 \%$ \\
\hline \multicolumn{7}{c}{$* p<0.05$ (SPSS). }
\end{tabular}

The data of Table 3 indicate that compound 2 is a more potent inhibitor of COX-2 than indomethacin. It also has less potency for COX-1 than indomethacin. A higher selectivity score is an indicator of higher selectivity for COX-2 inhibition [9]. The selectivity index (SI) of compound 2 was better than indomethacin (Figure 6). 


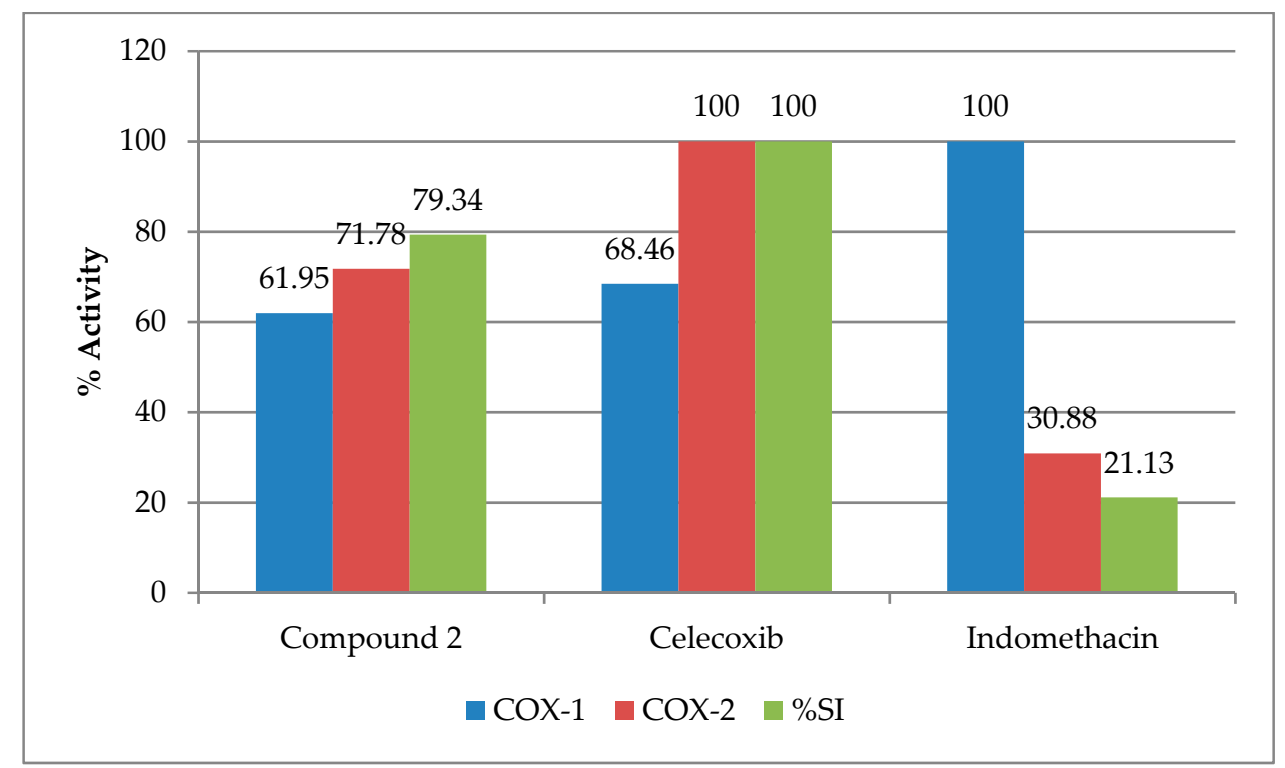

Figure 6. The \%COX-1/COX-2 inhibition and \%SI of compound 2, celecoxib and indomethacin.

\section{Materials and Methods}

\subsection{General}

The analytical/laboratory grade starting materials, chemicals, and reagents were procured from Merck and Sigma. Thermo scientific apparatus (9100) was used to note the melting point $\left({ }^{\circ} \mathrm{C}\right)$. The FTIR $\left(\mathrm{KBr}, \mathrm{cm}^{-1}\right)$ was recorded with the Shimadzu 440 spectrometer (Shimadzu, Tokyo, Japan). The ${ }^{1} \mathrm{H}-\mathrm{NMR}$ and ${ }^{13} \mathrm{C}$-NMR spectra (chemical shift $(\delta)$ in ppm) were recorded on Bruker's (Bruker BioSpin MRI GmbH, Ettlingen, Germany) instrument $\left(700 / 150 \mathrm{MHz}\right.$ spectrometer) in dimethylsulfoxide- $d_{6}\left(\right.$ DMSO- $\left.d_{6}\right)$.

\subsection{Synthesis of 2-Butyl-6-phenyl-4,5-dihydropyridazin-3(2H)-one (2)}

A solution of compound $\mathbf{1}(0.01 \mathrm{~mol})$ and anhydrous $\mathrm{K}_{2} \mathrm{CO}_{3}(0.02 \mathrm{~mol})$ was prepared in anhydrous acetone $(30 \mathrm{~mL})$. Analytical grade $n$-butyl bromide $(0.01 \mathrm{~mol})$ was added to this solution. The mixture was stirred at $25^{\circ} \mathrm{C}$ for $18 \mathrm{~h}$. The mixture was filtered and kept for $24 \mathrm{~h}$ and the solid was filtered and crystallized with ethanol and water mixture $(1: 1)$ at $25^{\circ} \mathrm{C}$. Yield $=55 \%$; shiny faint yellow solid; m.p. $=48-50{ }^{\circ} \mathrm{C} ; \mathrm{IR}\left(\mathrm{KBr}, \mathrm{cm}^{-1}\right)$ : $2929.12(\mathrm{C}-\mathrm{H}), 1670.56(\mathrm{C}=\mathrm{O}), 1560.28(\mathrm{C}=\mathrm{N}) ;{ }^{1} \mathrm{H}-\mathrm{NMR}\left(\mathrm{DMSO}-d_{6} ; \delta\right.$ in ppm): 0.89-0.91 (t, 3H, $\left.-\mathrm{CH}_{3}\right), 1.29-1.31\left(\mathrm{~d}, 2 \mathrm{H},-\mathrm{CH}_{2}-\mathrm{CH}_{3}\right), 1.59-1.61\left(\mathrm{t}, 2 \mathrm{H},-\mathrm{CH}_{2}-\mathrm{CH}_{2}-\mathrm{CH}_{3}\right), 2.49-2.52$ $\left(\mathrm{t}, 2 \mathrm{H},-\mathrm{CH}_{2}-\mathrm{CO}-\right), 2.96-2.98\left(\mathrm{t}, 2 \mathrm{H},-\mathrm{CH}_{2}-\mathrm{C}=\mathrm{N}\right), 3.73-3.75\left(\mathrm{t}, 2 \mathrm{H},-\mathrm{CH}_{2}-\mathrm{N}\right), 7.44-7.45(\mathrm{~d}, 3 \mathrm{H}, \mathrm{Ar}-\mathrm{H})$, 7.78-7.79 (d, 2H, Ar-H); ${ }^{13} \mathrm{C}-\mathrm{NMR}\left(\mathrm{DMSO}-d_{6} ; \delta\right.$ in ppm): $165.40(\mathrm{C}=\mathrm{O}), 150.83(\mathrm{C}=\mathrm{N}), 136.07(\mathrm{Ar}-\mathrm{C})$, 129.99 (Ar-C), 129.0 (2Ar-C), 126.27 (2Ar-C), $47.61\left(-\mathrm{CH}_{2}-\mathrm{N}\right), 30.34\left(-\mathrm{CH}_{2}-\mathrm{CO}-\right), 26.95\left(-\mathrm{CH}_{2}-\mathrm{C}=\mathrm{N}\right)$, $22.64\left(-\mathrm{CH}_{2}-\mathrm{CH}_{2}-\mathrm{CH}_{3}\right), 19.76\left(-\mathrm{CH}_{2}-\mathrm{CH}_{3}\right), 14.17\left(-\mathrm{CH}_{3}\right)$; Mass $(\mathrm{m} / \mathrm{z}): 229.98\left(\mathrm{M}^{+}\right), 228.96,186.98$, $158.98(\overline{100 \%}), 129.99,114.97,76 . \overline{95,54.97 .}$

\subsection{Molecular Docking Studies}

The Molecular Operating Environment (MOE) 2019.0102 (Chemical Computing Group Inc., Canada) was employed for the docking study of compound 2 in comparison to the selected non-steroidal anti-inflammatory drugs (NSAIDs). The COX-2 protein (PDB ID: 5KIR), and COX-1 protein (PDB IDs: 3KK6) were downloaded from the PDB database (https://www.rcsb.org/) $[10,16]$. The chain B of these proteins was selected for the docking purpose. The water molecules were removed from the selected protein chains, and the proteins were prepared for docking using the Quickprep functionality (default setting). The ligand structures were prepared on the MOE program using MOE builder. The partial charges were removed from the structures, and the energy was minimized. The mdb files of the ligands 
were stored as a library. The docking of the ligand with the selected proteins was performed with the default docking setting of the MOE-2019.0102. However, the number of poses was changed to 10 instead of 30. The docking scores (DS) and the root mean square deviation (RMSD) values were noted after the docking. The following parameters were calculated based on the DS of compounds $[7,8]$.

$$
\begin{gathered}
\text { Ligand efficiency }(\mathrm{LE})=\frac{\text { Docking score }}{\text { number of nonhydrogen atoms }} \\
\text { Inhibition constant }\left(\mathrm{K}_{\mathrm{i}}\right)=e^{[\text {Docking score } \div 1.366]} \\
\text { Ligand Efficiency Scale }\left(\mathrm{LE}_{\mathrm{Scale}}\right)=0.83 \times e^{-0.026 \times \mathrm{HA}}-0.064 \\
\text { Fit Quality }(\mathrm{FQ})=\frac{\mathrm{LE}}{\mathrm{LEScale}} \\
\text { Ligand Efficiency Lipophilic Price }\left(\text { LELP) }=\frac{\log \mathrm{P}}{\mathrm{LE}}\right.
\end{gathered}
$$

\subsection{Determination of the Physicochemical Properties and Drug-Likeness}

Analysis was performed by the Swiss web server (http://www.swissadme.ch/) [13]. The list of Simplified Molecular Input Line Entry System (SMILES) of compound 2, and selected Non-steroidal anti-inflammatory drugs (NSAIDs) were entered in the database, and the run button was pressed to get results. The obtained physicochemical parameters are listed in Table 2. The bioavailability radar (Supplementary Figure S1-1-S1-5) and the BOILED-Egg model for the pharmacokinetic parameters (Supplementary Figure S2) were also noted and analyzed.

\subsection{In Vitro COX-1 and COX-2 Inhibitory Activity Evaluation}

Analysis was performed by employing the identical methodology disclosed in our previous publication [9]. The $\mathrm{IC}_{50}$ values were determined using regression analysis. The selectivity index $\left(\mathrm{SI}=\mathrm{COX}-1\left(\mathrm{IC}_{50}\right.\right.$ in $\left.\mathrm{nM}\right) / \mathrm{COX}-2\left(\mathrm{IC}_{50}\right.$ in $\left.\left.\mathrm{nM}\right)\right)$ was also calculated. The data of this analysis are provided in Table 3.

\section{Conclusions}

The compound $\mathbf{2}$ is a novel potent COX-2 inhibitor in comparison to indomethacin. It is also expected to possess lesser ulcerogenic side effects than indomethacin because of its lower potency towards COX-1 inhibition. This compound also encompasses comparable promising physicochemical and pharmacokinetic profiles concerning other NSAIDs, including indomethacin. However, further toxicity investigations are needed to ensure the lead likeness of compound 2.

Supplementary Materials: The following are available online, Table S1 (Calculated common chemical identifiers of compound 2); Figure S1 (The bioavailability radar of compound 2, celecoxib, and indomethacin); Figure S1-1-S1-5 (Bioavailability radar of aspirin, diclofenac, naproxen, oxaprozin, and piroxicam); Figure S2 (The BOILED-Egg model representation of compound 2 and selected NSAIDs); Figures S3-S6 (FTIR, ${ }^{1} \mathrm{H}-\mathrm{NMR},{ }^{13} \mathrm{C}-\mathrm{NMR}$, and Mass spectra of compound 2).

Funding: This research received no external funding.

Acknowledgments: The author thanks Northern Border University for providing facilities to carry out this work.

Conflicts of Interest: The author declares no conflict of interest.

\section{References}

1. Asif, M. Diverse biologically active pyridazine analogs: A scaffold for the highly functionalized heterocyclic compounds. Rev. J. Chem. 2018, 8, 280-300. [CrossRef]

2. Dubey, S.; Bhosle, P.A. Pyridazinone: An important element of pharmacophore possessing broad spectrum of activity. Med. Chem. Res. 2015, 24, 3579-3598. [CrossRef] 
3. Saini, M.; Mehta, D.K.; Das, R.; Saini, G. Recent advances in anti-inflammatory potential of pyridazinone derivatives. Mini Rev. Med. Chem. 2016, 16, 996-1012. [CrossRef] [PubMed]

4. Singh, J.; Sharma, D.; Bansal, R. Pyridazinone: An attractive lead for anti-inflammatory and analgesic drug discovery. Future Med. Chem. 2017, 9, 95-127. [CrossRef] [PubMed]

5. Liang, L.; Yang, G.; Xu, F.; Niu, Y.; Sun, Q.; Xu, P. Copper-catalyzed aerobic dehydrogenation of C-C to C=C bonds in the synthesis of pyridazinones. Eur. J. Org. Chem. 2013, 2013, 6130-6136. [CrossRef]

6. Sircar, I. Substituted 6-Phenyl-3(2H)-pyridazinones Useful as Cardiotonic Agents. U.S. Patent 4404203, 13 September 1983.

7. Islam, M.A.; Pillay, T.S. Identification of promising anti-DNA gyrase antibacterial compounds using de novo design, molecular docking and molecular dynamics studies. J. Biomol. Struct. Dyn. 2020, 38, 1798-1809. [CrossRef] [PubMed]

8. Alamri, M.A. Pharmacoinformatics and molecular dynamic simulation studies to identify potential small-molecule inhibitors of WNK-SPAK/OSR1 signaling that mimic the RFQV motifs of WNK kinases. Arab. J. Chem. 2020, 13, 5107-5117. [CrossRef]

9. Khan, A.; Diwan, A.; Thabet, H.K.; Imran, M.; Bakht, M.A. Discovery of novel pyridazine-based cyclooxygenase-2 inhibitors with a promising gastric safety profile. Molecules 2020, 25, 2002. [CrossRef] [PubMed]

10. Orlando, B.J.; Malkowski, M.G. Crystal structure of rofecoxib bound to human cyclooxygenase-2. Acta Crystallogr. F Struct. Biol. Commun. 2016, 72 Pt 10, 772-776. [CrossRef]

11. Amin, N.H.; Mohammed, A.A.; Abdellatif, K.R. Novel 4-methylsulfonylphenyl derivatives as NSAIDS with preferential COX-2 inhibition. Future Med. Chem. 2018, 10, 53-70. [CrossRef] [PubMed]

12. Zhao, Y.H.; Abraham, M.H.; Le, J.; Hersey, A.; Luscombe, C.N.; Beck, G.; Sherborne, B.; Cooper, I. Rate-limited steps of human oral absorption and QSAR studies. Pharm. Res. 2002, 19, 1446-1457. [CrossRef] [PubMed]

13. Daina, A.; Zoete, V. Application of the SwissDrugDesign online resources in virtual screening. Int. J. Mol. Sci. 2019, 20, 4612. [CrossRef] [PubMed]

14. Daina, A.; Zoete, V. A BOILED-Egg to predict gastrointestinal absorption and brain penetration of small molecules. ChemMedChem 2016, 11, 1117-1121. [CrossRef] [PubMed]

15. Saxena, P.; Sharma, P.K.; Purohit, P. A journey of celecoxib from pain to cancer. Prostaglandins Other Lipid Mediat. 2020, 147, 106379. [CrossRef] [PubMed]

16. Rimon, G.; Sidhu, R.S.; Lauver, D.A.; Lee, J.Y.; Sharma, N.P.; Yuan, C.; Frieler, R.A.; Trievel, R.C.; Lucchesi, B.R.; Smith, W.L. Coxibs interfere with the action of aspirin by binding tightly to one monomer of cyclooxygenase-1. Proc. Natl. Acad. Sci. USA 2010, 107, 28-33. [CrossRef] [PubMed] 